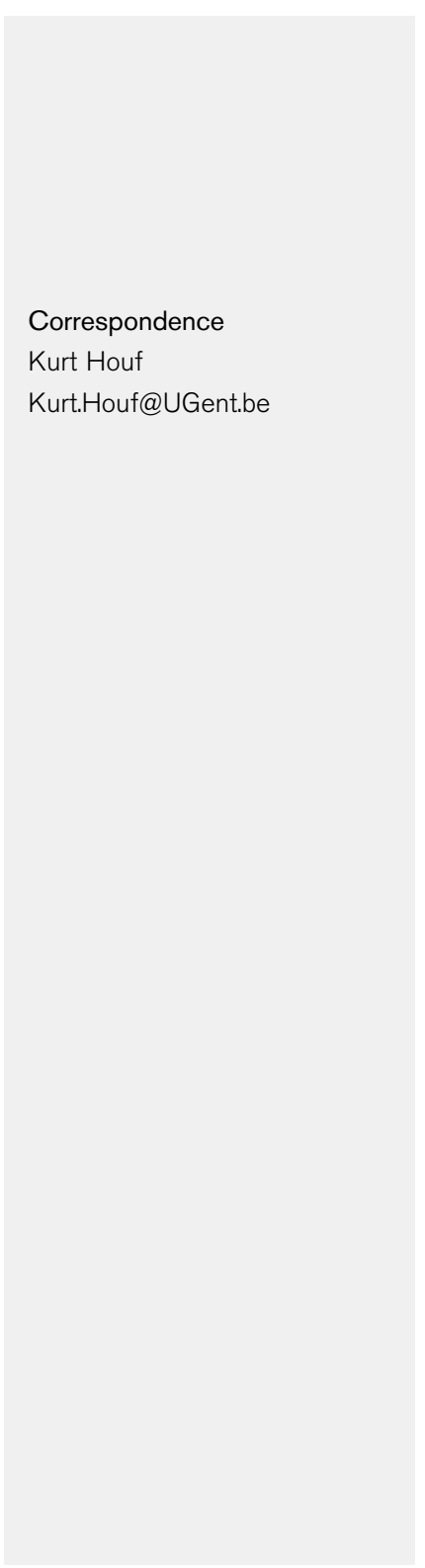

\title{
Arcobacter trophiarum sp. nov., isolated from fattening pigs
}

\author{
Sarah De Smet, ${ }^{1}$ Peter Vandamme, ${ }^{2}$ Lieven De Zutter, ${ }^{1}$ \\ Stephen L. W. On, ${ }^{3}$ Laid Douidah ${ }^{1}$ and Kurt Houf ${ }^{1}$ \\ ${ }^{1}$ Department of Veterinary Public Health and Food Safety, Faculty of Veterinary Medicine, Ghent \\ University, Salisburylaan 133, 9820 Merelbeke, Belgium \\ ${ }^{2}$ Department of Biochemistry and Microbiology, Faculty of Sciences, Ghent University, K. L. \\ Ledeganckstraat 35, 9000 Ghent, Belgium \\ ${ }^{3}$ Institute of Environmental Science and Research, Christchurch Science Center, 27 Creyke Road, \\ llamm, PO Box 29 181, Christchurch 8004, New Zealand
}

In the course of a longitudinal study elucidating the dynamics of Arcobacter populations in pigs, 16 isolates of Gram-reaction-negative, rod-shaped, slightly curved, non-spore-forming bacteria were grouped by amplified fragment length polymorphism analysis into a distinct phenon within the genus Arcobacter. Fragments were generated for all isolates in a genus-specific PCR assay, but no amplicon was obtained in a species-specific multiplex-PCR test. Numerical analysis of the whole-cell protein profiles also showed that all isolates clustered in a single group that was distinct from related members of the genus Arcobacter. DNA-DNA hybridizations between two representative strains, designated $64^{\top}$ and 122 , of the isolates obtained exhibited a mean DNADNA relatedness of $72 \%$. DNA-DNA hybridizations between strains $64^{\top}$ and 122 and reference strains of other animal-related bacteria of the genus Arcobacter revealed binding values of $47 \%$ or less. The DNA G+C contents of the two representative strains were 28.5 and 28.4 mol\%, respectively, and analysis of three marker genes identified Arcobacter cryaerophilus, $A$. thereius, A. cibarius and $A$. skirrowii as their closest phylogenetic neighbours. Strains $64^{\top}$ and 122 could be distinguished from other members of the genus Arcobacter by means of biochemical tests for catalase and urease activities, nitrate reduction, indoxyl acetate hydrolysis, lack of growth at $37{ }^{\circ} \mathrm{C}$, growth in $2 \%(\mathrm{w} / \mathrm{v}) \mathrm{NaCl}$, growth on $0.1 \%$ sodium deoxycholate and non-supplemented Campylobacter charcoal-deoxycholate base medium and resistance to cephalothin (32 $\mathrm{mg} \mathrm{I}^{-1}$ ) and cefoperazone $\left(64 \mathrm{mg} \mathrm{I}^{-1}\right)$. Additionally, a PCR assay was developed for the detection and identification of strains $64^{\top}$ and 122 , which represent a novel species of the genus Arcobacter, for which the name Arcobacter trophiarum sp. nov. is proposed. The type strain is strain $64^{\top}$ (=LMG $25534^{\top}=$ CCUG $59229^{\top}$ ).

In the late 1970s, Ellis et al. $(1977,1978)$ reported on the isolation of Campylobacter-like organisms from the internal organs of aborted porcine and bovine fetuses. These bacteria differed from previously described species of the genus Campylobacter in their ability to grow in air and at lower temperatures (Neill et al., 1979; Vandamme et al., 1992b). In 1991, the genus Arcobacter was proposed as a

Abbreviation: AFLP, amplified fragment length polymorphism.

The GenBank/EBML/DDBJ accession numbers for the partial sequences of the $16 \mathrm{~S}$ rRNA, 23S rRNA and hsp60 genes of strains $64^{\top}$ and 122 are FN650333, FN650334 and FN650337 and FN650332, FN650335 and FN650336, respectively.

Five supplementary figures and one supplementary table are available with the online version of this paper. second genus within the family Campylobacteraceae to encompass those bacteria formerly known as aerotolerant campylobacters (Vandamme et al., 1991). At the time of writing, nine species have been described in this genus, four of which are apparently only present in environmental matrices with the remaining five species being human or animal associated.

Arcobacter nitrofigilis, A. halophilus, A. mytili, A. marinus and a number of as-yet unclassified organisms, including 'Candidatus Arcobacter sulfidicus', have been isolated from sources such as coastal seawater, shellfish, sea sediment, salt-water lakes, water from underground cavities of oil wells and various kinds of sludge (Collado et al., 2009; Donachie et al., 2005; Kim et al., 2010; McClung et al., 1983; Wirsen et al., 2002). A. butzleri, A. cryaerophilus and 
A. skirrowii have been implicated in human illnesses, such as enteritis and septicaemia, and in reproductive disorders in livestock, as was described recently for the species Arcobacter thereius (Houf et al., 2009). However, isolation of these bacteria from clinically healthy animals has also been frequently reported (van Driessche et al., 2003). So far, the species Arcobacter cibarius has only been isolated from broiler carcasses and piggery effluent (Chinivasagam et al., 2007; Houf et al., 2005).

A. butzleri is the species that has been most predominantly associated with human infection, whereas $A$. cryaerophilus also seems to occur in humans but without clinical symptoms (Houf \& Stephan, 2007; Vandenberg et al., 2004). Routes of infection are still unclear but are assumed to be food- and waterborne. Contact with infected pets and person-to-person transmission have also been identified as potential routes of human infection (Fera et al., 2009; Houf et al., 2008; Petersen et al., 2007; Vandamme et al., 1992a).

In this study, we present the polyphasic taxonomic characterization of 16 Arcobacter isolates recovered from faecal samples taken rectally from 12 pigs on two Belgian farrow-to-finish farms during a longitudinal study of Arcobacter epidemiology within fattening pigs (Table 1). Samples (5 g) of faeces were enriched in $45 \mathrm{ml}$ Arcobacterselective broth containing $\left(1^{-1}\right) 24 \mathrm{~g}$ Arcobacter broth CM 0965 (Oxoid), $50 \mathrm{ml}$ lysed defibrinated horse blood (E\&O Laboratories) and a selective supplement, previously developed by Houf et al. (2001), comprising $\left(1^{-1}\right)$ $100 \mathrm{mg}$ 5-fluorouracil, $10 \mathrm{mg}$ amphotericin $\mathrm{B}, 16 \mathrm{mg}$

Table 1. Origin and identity of novel strains isolated during this study

All isolates were obtained from samples of pig faeces taken at farms in Belgium.

\begin{tabular}{|lc|}
\hline Strain number & Host no. and age (in weeks) \\
\hline $\mathrm{A} 1(\mathrm{~A} / 1 / 3$ enr $)$ & Pig $24(12)$ \\
$31(\mathrm{~B} / 2 / 2$ enr) & Pig $41(14)$ \\
$32(\mathrm{~B} / 2 / 2$ enr $)$ & Pig $42(14)$ \\
$36(\mathrm{~B} / 2 / 2$ enr $)$ & Pig $43(14)$ \\
$48(\mathrm{~B} / 2 / 2$ enr $)$ & Pig $44(14)$ \\
$64^{\mathrm{T}}=\mathrm{LMG} 25534^{\mathrm{T}}(\mathrm{B} / 2 / 2 \mathrm{~d} 5)$ & Pig $45(14)$ \\
$65(\mathrm{~B} / 2 / 2$ d7 $)$ & Pig $45(14)$ \\
$74(\mathrm{~B} / 2 / 2$ enr $)$ & Pig $48(14)$ \\
$85(\mathrm{~B} / 2 / 2$ enr $)$ & Pig $49(14)$ \\
$92(\mathrm{~B} / 2 / 2$ enr $)$ & Pig $50(14)$ \\
$95(\mathrm{~B} / 2 / 2 \mathrm{~d} 1)$ & Pig $50(14)$ \\
$101(\mathrm{~B} / 2 / 2$ d7 $)$ & Pig $50(14)$ \\
$108(\mathrm{~B} / 3 / 1$ enr $)$ & Pig $33(16)$ \\
$119(\mathrm{~B} / 3 / 1$ enr $)$ & Pig $36(16)$ \\
$122=\mathrm{LMG} 25535(\mathrm{~B} / 3 / 1$ enr $)$ & Pig $38(16)$ \\
$132(\mathrm{~B} / 3 / 2$ enr $)$ & Pig $43(16)$ \\
\hline
\end{tabular}

${ }^{*}$ Code: farm / sampling occasion / pen number ; d, isolated after quantitative analysis; enr, isolated after enrichment. cefoperazone, $32 \mathrm{mg}$ novobiocin and $64 \mathrm{mg}$ trimethoprim (Sigma). This was followed by inoculation on Arcobacterselective agar plates containing $\left(1^{-1}\right) 24 \mathrm{~g}$ Arcobacter broth, $12 \mathrm{~g}$ Agar Technical no. 3 LP 0013 (Oxoid) and the selective supplement described above, from which 12 isolates were recovered. Four isolates were recovered after direct plating of faecal material on the selective agar plates mentioned above. All incubations were performed at $28{ }^{\circ} \mathrm{C}$ in a microaerobic atmosphere and plates were checked every $24 \mathrm{~h}$ up to $72 \mathrm{~h}$ of incubation. Following incubation, small, colourless, translucent colonies were visible on Arcobacter-selective and blood agar plates. Typical bluish colonies were observed on these plates during examination with Henry transillumination, as previously reported for species of Arcobacter (Houf et al., 2009; Houf \& Stephan, 2007).

For molecular-based identification and characterization, genomic DNA from the 16 isolates was extracted using the guanidine thiocyanate method (Pitcher et al., 1989). The concentration of each DNA template was determined spectrophotometrically (BioPhotometer; Eppendorf) at $260 \mathrm{~nm}$ and adjusted to $50 \mathrm{ng} \mathrm{\mu l}^{-1}$. The DNA templates were stored at $-20{ }^{\circ} \mathrm{C}$. An expected $1223 \mathrm{bp}$ fragment was generated for all isolates using a genus-specific PCR assay (Harmon \& Wesley, 1996), but no fragments were obtained in a multiplex-PCR assay specific for A. butzleri, A. cibarius, A. cryaerophilus, A. skirrowii and A. thereius (Douidah et al., 2010).

Numerical analysis of amplified fragment length polymorphism (AFLP) profiles using an HhaI-HindIII-based protocol (Debruyne et al., 2010) was performed to identify and characterize the isolates and distinguish them from species of Campylobacter. This analysis identified 10 different AFLP profiles (data not shown) and clustered the 16 isolates together in a phenon distinct from characterized members of the genus Arcobacter.

Cluster analysis of DNA-banding patterns, obtained by a modified enterobacterial repetitive intergenic consensus PCR (Houf et al., 2002), confirmed the heterogeneity of the isolates. Based on criteria defined in previous studies (Houf et al., 2003; van Driessche et al., 2004), four main genotypes could be identified (see Supplementary Fig. S1, available in IJSEM Online).

Two strains, designated $64^{\mathrm{T}}$ and 122 , were selected for further genomic analysis. DNA-DNA hybridizations were performed with photobiotin-labelled probes in microplate wells as described by Ezaki et al. (1989), using a HTS7000 Bio Assay Reader (PerkinElmer) to measure fluorescence. DNA-DNA hybridization experiments, performed at $30{ }^{\circ} \mathrm{C}$, showed that strains $64^{\mathrm{T}}$ and 122 exhibited a mean DNA binding level of $72 \%$. Mean DNA-DNA relatedness between strains $64^{\mathrm{T}}$ and 122 and type strains of related Arcobacter species were as follows: $47 \%$ (A. cryaerophilus LMG $9904^{\mathrm{T}}$ ), $38 \%$ (A. skirrowii LMG $\left.6621^{\mathrm{T}}\right), 38 \%(A$. thereius LMG $\left.24486^{\mathrm{T}}\right), 36 \%\left(\right.$ A cibarius LMG $21996^{\mathrm{T}}$ ) and $31 \%$ (A. butzleri LMG $10828^{\mathrm{T}}$ ). The SD was $7 \%$. 
The DNA G $+\mathrm{C}$ contents of strains $64^{\mathrm{T}}$ and 122 were determined by enzymic degradation of DNA into nucleosides as described by Mesbah \& Whitman (1989). The mixture of nucleosides obtained was then separated by HPLC using a Waters Symmetry Shield C8 column thermostatted at $37^{\circ} \mathrm{C}$. The solvent used was $0.02 \mathrm{M}$ ammonium phosphate (pH 4) with $1.5 \%$ acetonitrile. Non-methylated $\lambda$-phage DNA (Sigma) was used as the calibration reference. The DNA G $+\mathrm{C}$ contents of $64^{\mathrm{T}}$ and 122 were 28.5 and $28.4 \mathrm{~mol} \%$, respectively, confirming previously reported low $\mathrm{G}+\mathrm{C}$ values for members of the family Campylobacteraceae (Vandamme et al., 1992a).

To determine the phylogenetic position of strains $64^{\mathrm{T}}$ and 122 , the partial sequences of the $16 \mathrm{~S}$ rRNA, $23 \mathrm{~S}$ rRNA and heat-shock protein 60 ( $h s p 60)$ genes were determined as described previously (Debruyne et al., 2010; Houf et al., 2009; Vandamme et al., 2006). Sequences were assembled using BioNumerics version 4.61 (Applied Maths) and aligned using the CLUSTAL_X software package (Thompson et al., 1997). Clustering was performed using the neighbour-joining (Saitou \& Nei, 1987), maximumlikelihood and maximum-parsimony methods using the BioNumerics version 4.61 software package. Unknown bases were discarded from the analysis and bootstrap values were determined using 500 replicates. Although the general topology of the reconstructed trees was not always identical, the different branching algorithms consistently revealed the same closely related species. Based on the $16 \mathrm{~S}$ rRNA gene sequences, searches using FASTA revealed that the closest phylogenetic neighbours to strains $64^{\mathrm{T}}$ and 122 were the type strains of A. cryaerophilus $(98.2 \%)$, A. thereius $(98.1 \%)$, A. cibarius $(97.8 \%)$ and A. skirrowii (97.4\%) (Supplementary Fig. S2). Analysis of $23 \mathrm{~S}$ rRNA gene sequences revealed that the nearest phylogenetic neighbour was A. thereius (98.2\%) (Fig. 1). Analysis of the hsp60 gene sequences were performed as described previously (Debruyne et al., 2010; Hill et al., 2006) and FASTA searches revealed that the nearest phylogenetic neighbours were the type strains of $A$. thereius $(92.4 \%)$, A. skirrowii $(91.3 \%)$ and A. cryaerophilus $(91.0 \%)$ (Supplementary Fig. S3). These results suggest that hsp60

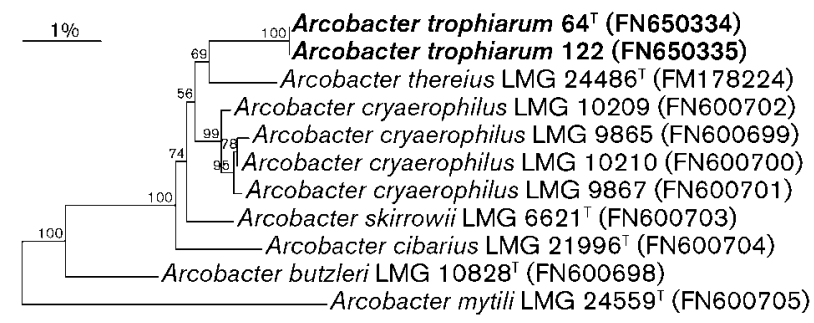

Fig. 1. Neighbour-joining phylogenetic tree based on $23 S$ rRNA gene sequences of strains $64^{\top}$ and 122 and related members of the genus Arcobacter. Bootstrap values are shown as percentages of 500 replicates. Bar, $1 \%$ sequence divergence. gene sequence analysis gives higher resolution compared with using rRNA gene sequences.

Whole-cell protein profiles were determined to further differentiate the novel isolates from related species of the genus Arcobacter. SDS-PAGE was performed using preparations of whole-cell proteins as described by Pot et al. (1994). The isolates were grown on Mueller-Hinton agar plates CM0337 (Oxoid) supplemented with 5\% (v/v) defibrinated horse blood and incubated microaerobically at $30{ }^{\circ} \mathrm{C}$. Whole-cell protein profiles of Arcobacter reference strains and reference strains of species of the genera Campylobacter and Helicobacter were available from previous studies (Houf et al., 2009; Vandamme et al., 1992a, b). Densitometric analysis, normalization and interpolation of the protein profiles and numerical analysis were performed using the GelCompar version 4.6.1 software package (Applied Maths). The similarity between all pairs of traces was expressed using Pearson's productmoment correlation coefficient and values were presented as percentages of similarity. The results of a numerical analysis of the protein profiles of the 16 isolates and Arcobacter reference strains are shown in Supplementary Fig. S4. All 16 of the novel isolates were grouped in a single cluster with a similarity levels above $84 \%$ and were clearly distinct from the reference strains of species of the genus Arcobacter (see Supplementary Fig. S4).

Over 20 phenotypic characteristics were tested in representatives of 10 species of the genus Arcobacter by using an extensive biochemical identification scheme for species of the genus Arcobacter and related bacteria as described by On et al. (1996). Comparison of these test results demonstrated several phenotypic differences between taxa. The relevant phenotypic characteristics that differentiated the novel strains from other taxa are given in Table 2. The inability to reduce nitrate differentiates the novel isolates from species with validly published names of the genus Arcobacter, except for A. cibarius and A. mytili. The inability to grow at $37^{\circ} \mathrm{C}$ under aerobic conditions differentiates the novel isolates from A. butzleri, A. skirrowii, A. mytili, A. halophilus and A. marinus. The inability to grow at $37{ }^{\circ} \mathrm{C}$ under microaerobic conditions distinguished the novel isolates from A. cibarius. Furthermore, the novel isolates could be differentiated from A. mytili based on their ability to grow on medium containing $64 \mathrm{mg}$ cefoperazone $1^{-1}$ and to hydrolyse indoxyl acetate. In contrast to A. halophilus and A. nitrofigilis, the novel isolates were able to grow on non-supplemented Campylobacter charcoal-deoxycholate base medium and were resistant to cephalothin $\left(32 \mathrm{mg} \mathrm{l}^{-1}\right)$ and cefoperazone $\left(64 \mathrm{mg} \mathrm{l}^{-1}\right)$. The novel isolates could be distinguished from $A$. halophilus by the presence of catalase activity and growth on medium containing $0.1 \%$ sodium deoxycholate. Furthermore, their inability to show urease activity differentiated the novel isolates from A. nitrofigilis. Apart from the inability to grow at $37{ }^{\circ} \mathrm{C}$ and to reduce nitrate to nitrite, the novel isolates can be distinguished from $A$. marinus by the ability to show catalase activity. 
Table 2. Characteristics that differentiate the novel isolates from representatives of other members of the genus Arcobacter

Taxa: 1, strains of Arcobacter trophiarum ( $n=10) ; 2$, A. butzleri $(n=12) ; 3$, A. cryaerophilus ( $n=19) ; 4$, A. skirrowii $(n=9) ; 5$, A. cibarius $(n=15)($ data from this study); 6, A. thereius ( $n=8) ; 7$, A. mytili (data from Collado et al., 2009 unless indicated; $n=3$ ); 8, A. nitrofigilis ( $n=2$ ); 9, A. halophilus $(n=1) ; 10$, A. marinus $(n=1)$ (Kim et al., 2010). Data from this study unless otherwise indicated. Values are percentages of strains that tested positive. CCDA, Campylobacter charcoal-deoxycholate base media. NT, Not tested.

\begin{tabular}{|c|c|c|c|c|c|c|c|c|c|c|}
\hline Characteristic & 1 & 2 & 3 & 4 & 5 & 6 & 7 & 8 & 9 & 10 \\
\hline Catalase activity & 100 & 33 & 100 & 100 & 54 & 100 & 100 & 100 & 0 & 0 \\
\hline Urease activity & 0 & 0 & 0 & 0 & 0 & 0 & 0 & 100 & 0 & 0 \\
\hline Indoxyl acetate hydrolysis & 100 & 100 & 100 & 100 & 100 & 100 & 0 & 100 & 100 & $100^{\dagger} / 0^{\ddagger}$ \\
\hline Alpha-haemolysis & 0 & 0 & 0 & 100 & 0 & 30 & 0 & 0 & NT & 0 \\
\hline Growth at $37{ }^{\circ} \mathrm{C}^{\dagger}$ & 0 & 100 & 58 & 100 & 100 & 0 & 100 & 0 & 100 & 100 \\
\hline \multicolumn{11}{|l|}{ Growth in: } \\
\hline Air at $25{ }^{\circ} \mathrm{C}$ & 100 & 100 & 100 & 100 & 31 & 100 & 100 & 100 & 100 & 100 \\
\hline Air at $37{ }^{\circ} \mathrm{C}$ & 0 & 100 & 50 & 100 & 0 & 0 & 100 & 50 & 100 & 100 \\
\hline $2 \%(\mathrm{w} / \mathrm{v}) \mathrm{NaCl}$ & 100 & 92 & 84 & 100 & 0 & 88 & 100 & 100 & 100 & 100 \\
\hline $4.0 \%(\mathrm{w} / \mathrm{v}) \mathrm{NaCl}$ & 40 & 0 & 0 & 100 & 0 & 0 & 100 & 100 & 100 & 100 \\
\hline \multicolumn{11}{|l|}{$\begin{array}{l}\text { Growth on media } \\
\text { containing: }\end{array}$} \\
\hline $\begin{array}{l}\text { Cephalothin } \\
\left(32 \mathrm{mg} \mathrm{l}^{-1}\right)\end{array}$ & 100 & 100 & 100 & 100 & 100 & 100 & $100^{*}$ & 0 & 0 & NT \\
\hline $\begin{array}{l}\text { Cefoperazone } \\
\left(64 \mathrm{mg} \mathrm{l}^{-1}\right)\end{array}$ & 100 & 100 & 100 & 100 & 100 & 100 & 0 & 0 & 0 & NT \\
\hline \multicolumn{11}{|l|}{ Growth on: } \\
\hline $\begin{array}{l}\text { Non-supplemented } \\
\text { CCDA }\end{array}$ & 100 & 100 & 100 & 100 & 60 & 75 & $100^{*}$ & 0 & 0 & NT \\
\hline MacConkey agar & 80 & 83 & 16 & 0 & 100 & 63 & 100 & 0 & 0 & NT \\
\hline
\end{tabular}

${ }^{*}$ Data from this study using A. mytili LMG $24559^{\mathrm{T}}$.

$\dagger$ Cells grown in microaerobic conditions.

$\ddagger$ Cells grown in aerobic conditions.

For electron microscopic analysis, strain $64^{\mathrm{T}}$ was grown on blood agar plates for $48 \mathrm{~h}$ at $28{ }^{\circ} \mathrm{C}$ under microaerobic conditions and the bacteria were harvested and fixed in HEPES buffer with $2.5 \%$ glutaraldehyde for $24 \mathrm{~h}$. The samples were post-fixed in $1 \%$ osmium tetroxide for $2 \mathrm{~h}$ at room temperature. The fixed samples were dehydrated through ascending grades of ethanol and transferred to a critical point drier CPD 030 (Bal-Tec). The dried tissues were mounted on a metal stub and sputter-coated with platinum using a JFC-1300 auto fine coater (JEOL). Examination of the samples was performed on a JEOL JSM 5600 LV scanning electron microscope. Cells of strain $64^{\mathrm{T}}$ appeared as slender rods, about $0.3-0.5 \mu \mathrm{m}$ wide and 1.4-2.0 $\mu \mathrm{m}$ long with a single unsheathed polar flagellum (Fig. 2).

For the identification of strains $64^{\mathrm{T}}$ and 122, a PCR assay with primers targeting the $h s p 60$ gene was developed and the sensitivity and specificity were evaluated to conform to previous studies (Houf et al., 2000; Douidah et al.,
2010). Reference strains of species of the genus Arcobacter and other closely related bacteria were obtained from the BCCM/LMG and CIP bacteria collections (see

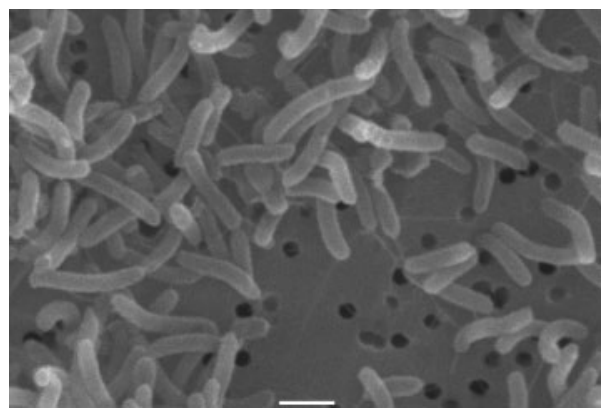

Fig. 2. Scanning electron micrograph of cells of strain $64^{\top}$. Bar, $1 \mu \mathrm{m}$. 
Supplementary Table S1). Arcobacter reference strains were grown on Mueller-Hinton agar plates supplemented with $5 \%$ defibrinated horse blood for $48 \mathrm{~h}$ at $30{ }^{\circ} \mathrm{C}$ and under microaerobic conditions obtained by evacuating $80 \%$ of the normal atmosphere and introducing a gas mixture of $8 \% \mathrm{CO}_{2}, 8 \% \mathrm{H}_{2}$ and $84 \% \mathrm{~N}_{2}$ into the jar. Cultivation of closely related organisms was performed according to their specific needs. PCRs were performed in a reaction mixture (50 $\mu \mathrm{l}$ final volumes) composed of sterile water (Sigma), $2 \mu \mathrm{l}$ bacterial DNA $\left(50 \mathrm{ng} \mu \mathrm{l}^{-1}\right), 5 \mu \mathrm{l} 10 \times$ PCR buffer (Invitrogen), $1.4 \mathrm{mmol} \mathrm{l}^{-1} \mathrm{MgCl}_{2}$ (Invitrogen), $2 \mathrm{U} \mathrm{Taq}$ DNA polymerase (Invitrogen), a dNTP mixture with each dNTP at a final concentration of $10 \mathrm{mmol}^{-1}$ (Invitrogen) and $50 \mathrm{pmol}$ of forward hsp60F (5'-TTGAACTTAAAAAAGCTTCGAG- $3^{\prime}$ ) and reverse hsp60R (5'-TCCATCAACATCTTCAGCTAC-3') primers (Invitrogen). A PerkinElmer Gene-Amp System 9700 thermocycler was used (Applied Biosystems). Prior to cycling, samples were heated at $94{ }^{\circ} \mathrm{C}$ for $3 \mathrm{~min}$. The PCR protocol involved 30 cycles of denaturation $\left(94{ }^{\circ} \mathrm{C}\right.$ for $\left.45 \mathrm{~s}\right)$, primer annealing $\left(58{ }^{\circ} \mathrm{C}\right.$ for $45 \mathrm{~s})$ and chain extension $\left(72{ }^{\circ} \mathrm{C}\right.$ for $\left.45 \mathrm{~s}\right)$, followed by a final elongation step at $72{ }^{\circ} \mathrm{C}$ for $5 \mathrm{~min}$. The PCR products $(10 \mu \mathrm{l})$ were size separated by electrophoresis at $100 \mathrm{~V}$ for $90 \mathrm{~min}$ in $1 \%$ agarose gels using $0.5 \mathrm{TBE}$ as a buffer. A Track-It 100 bp ladder (Invitrogen) was used as molecular mass marker. Gels were stained with ethidium bromide $\left(1 \mu \mathrm{g} \mathrm{ml}^{-1}\right)$ and DNA fragments were visualized by UV transillumination and photographed. The selected primers amplified a $383 \mathrm{bp}$ fragment of the $h s p 60$ gene of the novel isolates (see Supplementary Fig. S5). No PCR product was generated for closely related species of the genera Arcobacter, Campylobacter or Helicobacter, nor for strains of Escherichia coli and Salmonella enterica (not shown).

The occurrence of these novel isolates in the intestinal tract of healthy fattening pigs needs further attention and is of general interest for reasons of public health. Although the pathogenic potential of these strains is unknown, it is noteworthy that several related species (A. butzleri, A. cryaerophilus, A. cibarius and A. skirrowii) of the emerging pathogen Arcobacter were isolated from food of animal origin and have been implicated as sources of human infection. Moreover, the lack of growth at $37{ }^{\circ} \mathrm{C}$ of strains $64^{\mathrm{T}}$ and 122 and A. thereius (Houf et al., 2009) under laboratory conditions that allow cultivation of other hostassociated arcobacters is remarkable as they were all isolated from pigs. Recently, reliable and fast PCR-based methods for the detection of animal-related species of the genus Arcobacter have been developed. For example, a multiplex-PCR that can identify species A. butzleri, A. cryaerophilus, A. skirrowii, A. cibarius and A. thereius was described by Douidah et al. (2010). During the present study, a PCR assay for the detection and identification of a novel species of the genus Arcobacter has been developed. Although there is no evidence for the colonization of Arcobacter trophiarum sp. nov. in pigs, one pig continued to excrete the same strain for more than 2 weeks.
On the basis of their phylogenetic and phenotypic properties strains $64^{\mathrm{T}}$ and 122 represent a novel species of the genus Arcobacter, for which the name Arcobacter trophiarum sp. nov. is proposed.

\section{Description of Arcobacter trophiarum sp. nov.}

Arcobacter trophiarum (tro.phi.ar' um. Gr. n. trophias fattened animal or animal kept in stable; hence N.L. gen. pl. n. trophiarum of/from fattened animals or animals kept in stables).

Cells are slightly curved, Gram-reaction-negative rods, 1.4$2.0 \times 0.3-0.5 \mu \mathrm{m}$. They form whitish, slightly convex, nonswarming, smooth, rounded colonies with entire margins of about $2 \mathrm{~mm}$ in diameter on blood agar after $48 \mathrm{~h}$ of incubation at $28{ }^{\circ} \mathrm{C}$ under microaerobic conditions and translucent to opaque smooth-rounded colonies $1-2 \mathrm{~mm}$ in diameter on Arcobacter selective agar. In a microaerobic atmosphere, growth is observed after 2 days of incubation at room temperature $\left(18-22{ }^{\circ} \mathrm{C}\right)$ and $30{ }^{\circ} \mathrm{C}$ but not at 37 or $42{ }^{\circ} \mathrm{C}$. No growth occurs at $37{ }^{\circ} \mathrm{C}$ in aerobic conditions but does occur at 25 and $30{ }^{\circ} \mathrm{C}$ on blood agar. Produces oxidase and catalase and hydrolyses indoxyl acetate but does not show urease activity or reduction of nitrate. No alpha haemolysis is seen on blood agar. Grows under microaerobic conditions on non-supplemented Campylobacter charcoaldeoxycholate base media and on media containing $2 \%$ $\mathrm{NaCl}, 0.1 \%$ sodium deoxycholate, $32 \mathrm{mg}$ cephalothin $\mathrm{l}^{-1}$ and $64 \mathrm{mg}$ cefoperazone $\mathrm{l}^{-1}$. The majority $(\sim 80 \%)$ of known isolates grow on MacConkey agar and $~ 90 \%$ of known isolates grow on media containing $0.05 \%$ safranin.

The type strain, $64^{\mathrm{T}}\left(=\mathrm{LMG} 25534^{\mathrm{T}}=\right.$ CCUG $\left.59229^{\mathrm{T}}\right)$, was isolated from faeces of a 14-week-old piglet at a Belgian farm in 2007.

\section{Acknowledgements}

The skilled assistance of Evie Debrandt during sequence and hybridization analysis is greatly appreciated. We thank Tanya Scheifer and Stacey Anderson (Institute of Environmental Science and Research, New Zealand) for their excellent help in the performance of the biochemical analysis.

\section{References}

Chinivasagam, H. N., Corney, B. G., Wright, L. L., Diallo, I. S. \& Blackall, P. J. (2007). Detection of Arcobacter spp. in piggery effluent and effluent-irrigated soils in southeast Queensland. J Appl Microbiol 103, 418-426.

Collado, L., Cleenwerck, I., Van Trappen, S., De Vos, P. \& Figueras, M. J. (2009). Arcobacter mytili sp. nov., an indoxyl acetate-hydrolysisnegative bacterium isolated from mussels. Int J Syst Evol Microbiol 59, 1391-1396.

Debruyne, L., Houf, K., Douidah, L., De Smet, S. \& Vandamme, P. (2010). Reassessment of the taxonomy of Arcobacter cryaerophilus. Syst Appl Microbiol 33, 7-14.

Donachie, S. P., Bowman, J. P., On, S. L. W. \& Alam, M. (2005). Arcobacter halophilus sp. nov., the first obligate halophile in the genus Arcobacter. Int J Syst Evol Microbiol 55, 1271-1277. 
Douidah, L., De Zutter, L., Vandamme, P. \& Houf, K. (2010). Identification of five human and mammal associated Arcobacter species by a novel multiplex-PCR assay. J Microbiol Methods 80, 281-286.

Ellis, W. A., Neill, S. D., O'Brien, J. J., Ferguson, H. W. \& Hanna, J. (1977). Isolation of Spirillum/Vibrio-like organisms from bovine fetuses. Vet Rec 100, 451-452.

Ellis, W. A., Neill, S. D., O’Brien, J. J. \& Hanna, J. (1978). Isolation of spirillum-like organisms from pig fetuses. Vet Rec 102, 106.

Ezaki, T., Hashimoto, Y. \& Yabuuchi, E. (1989). Fluorometric deoxyribonucleic acid-deoxyribonucleic acid hybridization in microdilution wells as an alternative to membrane filter hybridization in which radioisotopes are used to determine genetic relatedness among bacterial strains. Int J Syst Bacteriol 39, 224-229.

Fera, M. T., La Camera, E., Carbone, M., Malara, D. \& Pennisi, M. G. (2009). Pet cats as carriers of Arcobacter spp. in Southern Italy. J Appl Microbiol 106, 1661-1666.

Harmon, K. M. \& Wesley, I. V. (1996). Identification of Arcobacter isolates by PCR. Lett Appl Microbiol 23, 241-244.

Hill, J. E., Paccagnella, A., Law, K., Melito, P. L., Woodward, D. L., Price, L., Leung, A. H., Ng, L. K., Hemmingsen, S. M. \& Goh, S. H. (2006). Identification of Campylobacter spp. and discrimination from Helicobacter and Arcobacter spp. by direct sequencing of PCRamplified cpn60 sequences and comparison to cpnDB, a chaperonin reference sequence database. J Med Microbiol 55, 393-399.

Houf, K. \& Stephan, R. (2007). Isolation and characterization of the emerging foodborn pathogen Arcobacter from human stool. J Microbiol Methods 68, 408-413.

Houf, K., Tutenel, A., De Zutter, L., Van Hoof, J. \& Vandamme, P. (2000). Development of a multiplex PCR assay for the simultaneous detection of Arcobacter butzleri, Arcobacter cryaerophilus and Arcobacter skirrowii. FEMS Microbiol Lett 193, 89-94.

Houf, K., Devriese, L. A., De Zutter, L., Van Hoof, J. \& Vandamme, P. (2001). Development of a new protocol for the isolation and quantification of Arcobacter species from poultry products. Int $J$ Food Microbiol 71, 189-196.

Houf, K., De Zutter, L., Van Hoof, J. \& Vandamme, P. (2002). Assessment of the genetic diversity among arcobacters isolated from poultry products by using two PCR-based typing methods. Appl Environ Microbiol 68, 2172-2178.

Houf, K., De Zutter, L., Verbeke, B., Van Hoof, J. \& Vandamme, P. (2003). Molecular characterization of Arcobacter isolates collected in a poultry slaughterhouse. J Food Prot 66, 364-369.

Houf, K., On, S. L. W., Coenye, T., Mast, J., Van Hoof, J. \& Vandamme, P. (2005). Arcobacter cibarius sp. nov., isolated from broiler carcasses. Int $J$ Syst Evol Microbiol 55, 713-717.

Houf, K., De Smet, S., Baré, J. \& Daminet, S. (2008). Dogs as carriers of the emerging pathogen Arcobacter. Vet Microbiol 130, 208-213.

Houf, K., On, S. L. W., Coenye, T., Debruyne, L., De Smet, S. \& Vandamme, P. (2009). Arcobacter thereius sp. nov., isolated from pigs and ducks. Int J Syst Evol Microbiol 59, 2599-2604.

Kim, H. M., Hwang, C. Y. \& Cho, B. C. (2010). Arcobacter marinus sp. nov. Int J Syst Evol Microbiol 60, 531-536.

McClung, C. R., Patriquin, D. G. \& Davis, R. E. (1983). Campylobacter nitrofigilis sp. nov., a nitrogen-fixing bacterium associated with roots of Spartina alterniflora Loisel. Int J Syst Bacteriol 33, 605-612.

Mesbah, M. \& Whitman, W. B. (1989). Measurement of deoxyguanosine/thymidine ratios in complex mixtures by high-performance liquid chromatography for determination of the mole percentage guanine + cytosine of DNA. J Chromatogr 479, 297-306.
Neill, S. D., Ellis, W. A. \& O'Brien, J. J. (1979). Designation of aerotolerant Campylobacter-like organisms from porcine and bovine abortions to the genus Campylobacter. Res Vet Sci 27, 180-186.

On, S. L. W., Holmes, B. \& Sackin, M. J. (1996). A probability matrix for the identification of campylobacters, helicobacters and allied taxa. J Appl Bacteriol 81, 425-432.

Petersen, R. F., Harrington, C. S., Kortegaard, H. E. \& On, S. L. W. (2007). A PCR-DGGE method for detection and identification of Campylobacter, Helicobacter, Arcobacter and related Epsilobacteria and its application to saliva samples from humans and domestic pets. J Appl Microbiol 103, 2601-2615.

Pitcher, D. G., Saunders, N. A. \& Owen, R. J. (1989). Rapid extraction of bacterial genomic DNA with guanidium thiocyanate. Lett Appl Microbiol 8, 151-156.

Pot, B., Vandamme, P. \& Kersters, K. (1994). Analysis of electrophoretic whole-organism protein fingerprints. In Chemical Methods in Prokaryotic Systematics, pp. 493-521. Edited by M. Goodfellow \& A. G. O’Donnell. Chichester: Wiley.

Saitou, N. \& Nei, M. (1987). The neighbor-joining method: a new method for reconstructing phylogenetic trees. Mol Biol Evol 4, 406425 .

Thompson, J. D., Gibson, T. J., Plewniak, F., Jeanmougin, F. \& Higgins, D. G. (1997). The CLUSTAL_X windows interface: flexible strategies for multiple sequence alignment aided by quality analysis tools. Nucleic Acids Res 25, 4876-4882.

van Driessche, E., Houf, K., Van Hoof, J., De Zutter, L. \& Vandamme, P. (2003). Isolation of Arcobacter species from animal feces. FEMS Microbiol Lett 229, 243-248.

van Driessche, E., Houf, K., Vangroenweghe, F., Nollet, N., De Zutter, L., Vandamme, P. \& Van Hoof, J. (2004). Occurrence and strain diversity of Arcobacter species isolated from healthy Belgian pigs. Res Microbiol 155, 662-666.

Vandamme, P., Falsen, E., Rossau, R., Hoste, B., Segers, P., Tytgat, R. \& De Ley, J. (1991). Revision of Campylobacter, Helicobacter, and Wolinella taxonomy: emendation of generic descriptions and proposal of Arcobacter gen. nov. Int J Syst Bacteriol 41, 88-103.

Vandamme, P., Vancanneyt, M., Pot, B., Mels, L., Hoste, B., Dewettinck, D., Vlaes, L., Van Den Borre, C., Higgins, R. \& other authors (1992a). Polyphasic taxonomic study of the emended genus Arcobacter with Arcobacter butzleri comb. nov. and Arcobacter skirrowii sp. nov., an aerotolerant bacterium isolated from veterinary specimens. Int J Syst Bacteriol 42, 344-356.

Vandamme, P., Pugina, P., Benzi, G., Vanetterijck, R., Vlaes, L., Kersters, K., Butzler, J. P., Lior, H. \& Lauwers, S. (1992b). Outbreak of recurrent abdominal cramps associated with Arcobacter butzleri in an Italian school. J Clin Microbiol 30, 2335-2337.

Vandamme, P., Holmes, B., Bercovier, H. \& Coenye, T. (2006). Classification of Centers for Disease Control Group Eugonic Fermenter (EF)-4a and EF-4b as Neisseria animaloris sp. nov. and Neisseria zoodegmatis sp. nov., respectively. Int J Syst Evol Microbiol 56, 1801-1805.

Vandenberg, O., Dediste, A., Houf, K., Ibekwem, S., Souayah, H., Cadranel, S., Douat, N., Zissis, G., Butzler, J. P. \& Vandamme, P. (2004). Arcobacter species in humans. Emerg Infect Dis 10, 1863-1867.

Wirsen, C. O., Sievert, S. M., Cavanaugh, C. M., Molyneaux, S. J., Ahmad, A., Taylor, L. T., Delong, E. F. \& Taylor, C. D. (2002). Characterization of an autotrophic sulfide-oxidizing marine Arcobacter sp. that produces filamentous sulfur. Appl Environ Microbiol 68, 316-325. 